Fundamentals in British Politics 
Related titles

Patrick Dunleavy, Andrew Gamble, Ian Holliday and Gillian Peele (eds)

DEVELOPMENTS IN BRITISH POLITICS 5

Peter A. Hall, Jack Hayward and Howard Machin (eds) DEVELOPMENTS IN FRENCH POLITICS (Revised Edition)

Gillian Peele, Christopher Bailey, Bruce Cain and B. Guy Peters (eds)

DEVELOPMENTS IN AMERICAN POLITICS 3

Martin Rhodes, Paul Heywood and Vincent Wright (eds) DEVELOPMENTS IN WEST EUROPEAN POLITICS

Gordon Smith, William E. Paterson and Stephen Padgett (eds)

DEVELOPMENTS IN GERMAN POLITICS 2

Stephen White, Judy Batt and Paul G. Lewis (eds) DEVELOPMENTS IN EAST EUROPEAN POLITICS 2

Stephen White, Alex Pravda and Zvi Gitelman (eds) DEVELOPMENTS IN RUSSIAN POLITICS 4 


\title{
Fundamentals in British Politics
}

\author{
Edited by \\ Ian Holliday \\ Andrew Gamble \\ and \\ Geraint Parry
}

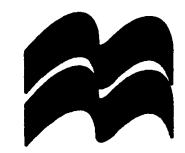


Editorial matter and selection (C) Ian Holliday, Andrew Gamble and Geraint Parry 1999

Individual chapters (in order) (C) Geraint Parry; Andrew Gamble; Nevil Johnson; Gillian Peele; Martin J. Smith; Ian Holliday;

Robert Thomas; Robert Reiner; Michael Moran; Patrick Dunleavy; Elizabeth Meehan; John Peterson; Michael Kenny 1999

All rights reserved. No reproduction, copy or transmission of this publication may be made without written permission.

No paragraph of this publication may be reproduced, copied or transmitted save with written permission or in accordance with the provisions of the Copyright, Designs and Patents Act 1988, or under the terms of any licence permitting limited copying issued by the Copyright Licensing Agency, 90 Tottenham Court Road, London W1P 0LP.

Any person who does any unauthorized act in relation to this publication may be liable to criminal prosecution and civil claims for damages.

The authors have asserted their rights to be identified as the authors of this work in accordance with the Copyright, Designs and Patents Act 1988.

First published 1999 by

MACMILLAN PRESS LTD

Houndmills, Basingstoke, Hampshire RG21 6XS

and London

Companies and representatives

throughout the world

ISBN 978-0-333-71097-5

DOI 10.1007/978-1-349-27696-7

A catalogue record for this book is available from the British Library.

This book is printed on paper suitable for recycling and made from fully managed and sustained forest sources.

$\begin{array}{llllllllll}10 & 9 & 8 & 7 & 6 & 5 & 4 & 3 & 2 & 1\end{array}$

$\begin{array}{llllllllll}08 & 07 & 06 & 05 & 04 & 03 & 02 & 01 & 00 & 99\end{array}$

Copy-edited and typeset by Povey-Edmondson Tavistock and Rochdale, England

Published in the United States of America by

ST. MARTIN'S PRESS, INC.,

Scholarly and Reference Division

175 Fifth Avenue, New York, N.Y. 10010

ISBN 978-0-312-22649-7(cloth)

ISBN 978-0-312-22650-3(paper) 


\section{Contents}

List of Contributors viii

1 Introduction Geraint Parry 1

The Commonalities of the Modern Liberal-Democratic State 3

British Political Fundamentals in Question $\quad 6$

Fundamentals and Power 18

2 State, Economy and Society Andrew Gamble 21

The Modern State $\quad 22$

The British State as a Liberal State 24

An Ancien Régime?

The State as an Enterprise $\quad 30$

Capitalism $\quad 32$

Empire $\quad 36$

Welfare $\quad 40$

Conclusion $\quad 44$

3 The Constitution Nevil Johnson 45

Constitutions, Ancient and Modern 45

Fundamental in What Sense? 47

Fundamentals in Practice 49

Parliament and Parliamentary Government 54

The Judicial Power $\quad 59$

The Established Churches 61

Checks and Balances and the Sovereign People 63

The Constitution Under Fire 65

4 The Growth of the State Gillian Peele 71

What is the State? 72

The Growth of the Modern State 73

The Changing Pattern of Governmental Functions 86

The Organization of the State 93

Conclusion $\quad 94$ 


\section{The Institutions of Central Government} Martin J. Smith 96

The Principles of British Central Government 96

The Development of the Administrative Machine $\quad 98$

Developing Collective Responsibility 102

Undermining the Westminster Model 109

New Approaches to Central Government 115

Conclusion 118

6 Territorial Politics Ian Holliday 119

The Making of the UK 119

Analysing the UK 122

The Primacy of EC Law 124

Parliamentary Sovereignty 125

Territorial Representation $\quad 126$

Local Government $\quad 128$

Administrative Decentralization 131

Central Supervision and Control 133

Union Maintenance 136

Nationalist Challenges to the Fundamentals of UK Territorial Politics

Conclusion 139

7 Law and Politics Robert Thomas 142

Law and Politics in Britain $\quad 142$

The Development of Judicial Review 148

The Politics of the Judiciary 153

Fusion of Powers 155

The Impact of EC Law 157

The Human Rights Act $1998 \quad 158$

$\begin{array}{ll}\text { Conclusion } & 161\end{array}$

8 Order and Discipline Robert Reiner 163

What is Order? 164

Waves of Order 168

Formal and Informal Control 170

Beyond Order? From Repression to Reflexivity 178

9 Estates, Classes and Interests Michael Moran 182

The Creation of Class Politics 184

The Crisis of the Governing Order 191

Reshaping Interests 196

Revisiting the Fundamentals 201 
10 Electoral Representation and Accountability: The Legacy of Empire Patrick Dunleavy

The Westminster Model and Why It Endured 205

The Origins of a Modernised View of Representation 221

Conclusions: Political Representation in Britain 229

11 Citizenship and Identity Elizabeth Meehan 231

British Debates about Citizenship $\quad 232$

Citizenship and Identity 239

A New Language of Citizenship which Incorporates

Diverse Identities

12 Sovereignty and Interdependence John Peterson 251

The Legacy of Empire 258

Britain and the European Project 262

Globalization and Britain PLC 268

Conclusion $\quad 272$

13 Ideas, Ideologies and the British Political Tradition

Michael Kenny

275

Tradition or Ideology? $\quad 276$

Defining 'the British Tradition' 277

Individualism $\quad 283$

Liberalism 288

The Left-Right Ideological Spectrum 297

Conclusion 298

Guide to Further Reading 301

Bibliography 306

Index $\quad 326$ 


\section{List of Contributors}

Patrick Dunleavy is Professor of Government at the London School of Economics. Educated at Corpus Christi College, Oxford, and Nuffield College, Oxford, he worked at the Open University before moving to the LSE in 1979. He is a long-time editor of the Developments in British Politics series, and has published Democracy, Bureaucracy and Public Choice (1991) and many other books and papers.

Andrew Gamble is Professor of Politics and Director of the Political Economy Research Centre at the University of Sheffield. Recent publications include Hayek: The Iron Cage of Liberty, and journal articles on economic governance, the politics of ownership and comparative political economy.

Ian Holliday is Professor of Policy Studies at the City University of Hong Kong. Recent publications include The British Cabinet System (co-authored) and journal articles on British politics and policy. He co-edits the journal Party Politics.

Nevil Johnson was from 1969 to 1996 Nuffield Reader in the Comparative Study of Institutions in the University of Oxford and a Professional Fellow of Nuffield College where he is now an Emeritus Fellow. He has written extensively on British and German political institutions, and has a special interest in constitutionalism and the theory of institutions. His books include In Search of the Constitution (1977) and The Limits of Political Science (1989).

Michael Kenny is Lecturer in Politics at the University of Sheffield. Recent publications include The First New Left: British Intellectuals after Stalin and Rethinking British Decline (co-edited). He is the author of journal articles on British political thought, ethics and cultural policy, and the insights offered by modern political thought into contemporary international society.

Elizabeth Meehan is Professor of Politics at the Queen's University of Belfast. Recent publications deal with citizenship and the EU, devolution in the UK and British-Irish relations. Examples are 'European Integration and Citizens' Rights: A Comparative Perspective', Publius: The Journal of Federalism (1996); 'Citizenship and Social Inclusion', in M. Roche (ed.) European Citizenship and Social Exclusion 
(1997); 'The Belfast Agreement: Distinctiveness and Cross-Fertilization in the UK's Devolution Programme', Parliamentary Affairs (1999).

Michael Moran is Professor of Government in the University of Manchester. He is co-author of the best-selling textbook Politics $U K$, and researches on comparative public policy. His most recent book is Governing the Health Care State.

Geraint Parry is the W. J. M. Mackenzie Professor of Government at the University of Manchester. Recent publications include Political Participation and Democracy in Britain (co-authored) and Democracy and Democratization (co-edited), and journal articles on political theory and political education. He is editor of the journal Government and Opposition.

Gillian Peele is Fellow and Tutor in Politics at Lady Margaret Hall, Oxford. She is the author of Governing the UK (1995) and a co-editor of Developments in British Politics 5 (1997) and of Developments in American Politics 3 (1998).

John Peterson is Jean Monnet Professor of European Politics at the University of Glasgow. Recent publications include Decision-Making in the European Union (co-authored), A Common Foreign Policy for Europe? (co-edited) and Technology Policy in the European Union (coauthored).

Robert Reiner is Professor of Criminology in the Law Department, London School of Economics. Among his recent books are Chief Constables (1991), The Politics of the Police (2nd edn, 1992) and Policing (1996). He was President of the British Society of Criminology from 1993 to 1996 . His present research is an ESRC-funded study of changing media representations of crime and criminal justice in Britain since the Second World War.

Martin J. Smith is Professor of Politics at the University of Sheffield. He has published widely on British politics and comparative public policy. His recent publications include The Core Executive in Britain and Quangos, Accountability and Reform (co-edited).

Robert Thomas is Lecturer in Law at the University of Manchester. He has recently obtained his doctorate on the relationship between English and European Community administrative law, and is currently turning this study into a book. 